\title{
PEMANFAATAN KULIT MANGGIS (Garcinia mangostana L) SEBAGAI FORMULASI TABLET ANTI KANKER YANG PRAKTIS DAN EKONOMIS
}

\author{
Shalahuddin Al Madury (11613095), Farida Fakhrunnisa (11613037), \\ Azizah Amin (11613 143). \\ Jurusan Farmasi, Fakultas MIPA
}

\begin{abstract}
Abstrak
Based on data from the World Health Organization (WHO 2010) deadly disease cancer is number two in the world after heart disease. Therefore, there is need for intensive treatment to overcome these health problems, as proclaimed in the draft long-term development of health of the Republic of Indonesia. One of the plants can be used as an anticancer is mangosteen, Garcinia mangostana $L$. This plant contains a compound-mangostin xanthone especially play a role in cancer treatment with antioxidants that work crate scavenge free radicals so that a non-radical compounds. Required best alternative in tablet dosage that use more practical and economical as the innovation of the preparation syrups tend to be more complicated and expensive. The method used in this study using the literature method. From the discussion carried out could be concluded that mangosteen peel extract (Garcinia mangostana $L$ ) is effective for the treatment of cancer with good stability and a practical and economical, so is very potential to be accepted by society.
\end{abstract}

Keywords: Cancer, Skin Extract Mangosteen (Garcinia mangostana L), Tablet, Practical, Economical.

\section{PENDAHULUAN}

\section{Latar Belakang}

Rencana Pembangunan Jangka Panjang bidang kesehatan (RPJP) Indonesia tahun 2005-2025 menyebutkan bahwa, tantangan masa depan pembangunan kesehatan adalah pencegahan dan pemberantasan penyakit salah satunya penyakit jantung, kardio-

vaskular, kanker, dan penyakit tidak menular lainnya (Anonim, 2009). Semakin tahun penderita kanker di dunia terus bertambah. Jumlah kasus baru dan kematian akibat kanker pun semakin meningkat. Bahkan diperkirakan jumlah penderita kanker di dunia naik hingga 300 kali lipat pada tahun 2030 dibandingkan dengan tahun 2005. 
Berdasarkan data Badan Kesehatan Dunia (WHO tahun 2010) penyakit kanker merupakan penyakit mematikan nomer dua di dunia setelah penyakit jantung. Pada tahun 2005 kematian akibat kanker di seluruh dunia mencapai 7 juta orang, 11 juta kasus baru kanker dan 25 juta orang hidup dengan kanker. Diperkirakan pada tahun 2030, kematian akibat kanker meningkat menjadi 17 juta, 27 juta kasus baru dan 75 juta orang hidup dengan kanker. Dari 75 juta jiwa tersebut, 70 persennya hidup di negara berkembang termasuk Indonesia (Anonim, 2012 ${ }^{\mathrm{a}}$ ).

Indonesia dikenal sebagai salah satu dari tujuh negara dengan keanekaragaman hayati terbesar, sebenarnya tanaman obat (herbal) telah lama dikenal sebagai pengobatan tradisional oleh orang-orang terdahulu karena masyarakat berpedoman bahwa obat tradisional lebih kecil resikonya daripada bahan kimia (Isa, 2009). Fakta ini tentu memiliki potensi dalam pengembangan obat herbal yang berbasis pada tumbuhan obat dalam usaha kemandirian di bidang kesehatan. Tumbuhan tersebut menghasilkan senyawa metabolit sekunder dengan struktur molekul dan aktivitas biologi yang beranekaragam. Beberapa senyawa yang telah terbukti memiliki aktivitas sebagai antikanker, antara lain golongan alkaloid, terpenoid, flavonoid, xanton, dan kumarin (Oktaviani, 2010).

Salah satu senyawa yang telah banyak dilaporkan memiliki aktivitas anti kanker adalah xanton. Xanton merupa- kan senyawa terbesar yang ditemukan pada famili clusiaceae khususnya dari spesies Garcinia. Senyawa santon yang berhasil diisolasi dari tanaman manggis (Garciniamangostana), diantaranya á-mangostin telah terbukti bersifat sebagai anti kanker ( $\mathrm{Na}, 2009)$.

Riset Dwi Oktaviani J dan Taslim Ersandari Jurusan Kimia Teknologi Sepuluh Nopember, menunjukkan 1,4,5,7-tetrahidrosi-2 (1,1 dimetilalil) xantone berpotensi sebagai obat anti kanker baru. Terbukti tikus yang telah diinjeksi benzapiren-promotorkankermemiliki nilai melondialdehid yang hamper sama dengan tikus sehat.

Pemikiran tersebut melatarbelakangi pemanfaatanekstrak kulit manggis (Garcinia mangostana L) sebagai salah satu bahan alami yang digunakan untuk pengobatan kanker. Ekstrak kulit manggis dapat dibuat dalam berbagai bentuk sediaan farmasetika. Salah satu sediaan yang ada adalah sirup, akan tetapi penulis ingin mengembangkannya dalam formulasi bentuk sediaan tablet yang lebih praktis dan harga murah.

Tablet memiliki beberapa keuntungan dibandingkan sediaan-sediaan lain termasuk sirup yaitu lebih cepat diabsorbsi, sehingga memberikan efek terapi yang lebih cepat, kompatibilitas yang yang optimal, meningkatkan intake cairan tubuh, dan praktis dalam penggunaannya (Anonim, 2004). Tablet kulit manggis akan memberikan rasa yang nyaman, efisien, dan praktis dalam penggunaannya. 
Berdasarkan latar belakang diatas, penelitian ini diharapkan dapat menjawab rumusan masalah sebagai berikut:

1. Apakah ekstrak kulit manggis (Garcinia mangostana L)dapat dibuat menjadi sediaan tablet yang diharapkan melalui pengujian lanjut dapat efektif digunakan untuk terapi pada penyakit kanker?

2. Bagaimana stabilitas sediaan tablet yang diformulasi dari kulit manggis (Garcinia mangostana L)?

3. Apakah sediaan tablet kuli manggis (Garcinia mangostana L) berpotensi dapat diterima masyarakat dengan pertimbangan praktis dan nilai ekonomis yang lebih murah dengan perbandingan harga produk sejenis yang ada di pasaran?

\section{TINJAUAN PUSTAKA}

\section{Kanker}

Tumor merupakan masa jaringan yang tumbuh abnormal dengan pertumbuhan yang pada hakekatnya bersifat otonom dan melampaui pertumbuhan jaringan normal. Pertumbuhan tumor terus menetap seklaipun stimulus yang memulai pertumbuhan tersebut sudah berhenti. Tumor diklasifikasikan menjadi dua katagori yaitu tumor ganas dan tumor jinak. Tumor ganas biasa disebut dengan nama kanker (Mitchell, 2006)

Kanker adalah istilah yang diterapkan untuk penyakit ganas yang mempengaruhi bagian yang berbeda dari tubuh. Penyakit ini ditandai dengan pembentukan cepat dan tidak terkendali dari sel-sel abnormal, yang mungkin massal bersama-sama untuk membentuk suatu pertumbuhan atau tumor, atau berkembang biak di seluruh tubuh, memulai pertumbuhan abnormal disitus lain. Jika proses ini tidak ditangkap kemajuan, mungkin sampai menyebabkan kematian organisme. Kanker uncountered di semua hewan tingkat tinggi, dan tanaman juga mengembangkan pertumbuhan yang menyerupai kanker. (Hoffmann, 2003).

Faktor resiko yang menyebabkan kanker yaitu :

1. Riwayat keluarga atau keturunan

2. Pemaparan yang berlebih dari sinar ultraviolet, terutama sinar matahari yang dapat menyebabkan kanker kulit.

3. Radiasi ionisasi (yang merupakan karsinogenik) digunakan dalam sinar X, dihasilkan dari pembangkit listrik tenaga nuklir dan ledakan bom Atom dan bisa menjangkau jarak yang sangat jauh.

4. Makanan, makanan merupakan salah satu penyebab kanker terutama makanan-makanan yang mengandung bahan pengawet dan makanan-makanan yang menyebabkan radikal bebas dalam tubuh.

5. Perokok

6. Terpapar Virus seperti Virus papilloma yang menyebabkan kanker serviks, dan lainnya. (Anonim, 2012 ${ }^{\text {b }}$ )

Kanker yang disebut juga dengan neoplasma ganas memiliki sifat yang sangat berbahaya. la tumbuh lebih cepat 
dan tumbuh secara progressif, jika tidak dibuang. Akibatnya pola penyebarannya saringkali tidak teratur. Jadi, dua bahaya dari neoplasma ganas yaitu kemampuannya menginvasi jaringan normal dan kemampuannya membentuk metastasis.salah satu cara terjadinya metastasis adalah adanya infasi pembuluh darah yang mengakibatkan metastasis hematogen (Price, 1995).

\section{Manggis}

Tanaman manggis merupakan tanaman yang berbuah musiman. Manggis sejenis pohon hijau abadi dari daerah tropika yang diyakini berasal dari Kepulauan Nusantara. Tumbuh hingga mencapai 7 sampai 25 meter. Buahnya juga disebut manggis, berwarna merah keunguan ketika matang, meskipun ada pula varian yang kulitnya berwarna merah. Buah manggis dalam perdagangan dikenal sebagai "ratu buah", sebagai pasangan durian, si "raja buah". Buah ini mengandung mempunyai aktivitas antiinflamasi dan antioksidan. Sehingga di luar negeri buah manggis dikenal sebagai buah yang memiliki kadar antioksidan tertinggi di dunia. Klasifikasi ilmiah dari buah manggis sebagai berikut:

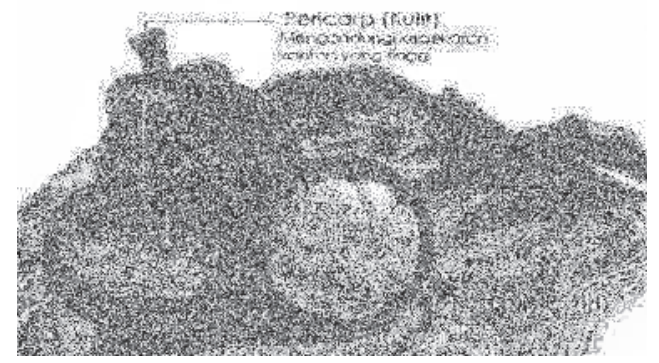

Gambar 1. Buah Manggis(Garcinia mangostanaL.) (Anonim, 2012 ${ }^{\mathrm{C}}$ )

$\begin{array}{ll}\text { Kerajaan } & \text { : Plantae } \\ \text { Divisi } & \text { : Magnoliophyta } \\ \text { Kelas } & \text { : Magnoliopsida } \\ \text { Ordo } & \text { : Malpighiales } \\ \text { Famili } & : \text { Clusiaceae } \\ \text { Genus } & \text { : Garcinia } \\ \text { Spesies } & \text { : G. mangostana } \\ \text { Buah dengan nama latin Garcinia }\end{array}$
mangostana $L$ memiliki segudang manfaat baik dari isi, biji, sampai kulitnya. Kulitnya mengandung senyawa amangstin dari golongan senyawa xanthone. Senyawa ini merupakan zat antioksidan yang dapat menangkap radikal bebas dalam tubuh. Senyawa ini memiliki banyak kegunaan bagi kesehatan tubuh. Beberapa penelitian, salah satunya yang termuat dalam Journal of Pharmacy and Pharmacology menyebutkan bahwa xanthone mempunyai fungsi sebagai obat kanker ( $\mathrm{Na}, 2009)$. Selain itu juga, senyawa dari kulit buah manggis ini juga memiliki aktivitas sebagai dengan atau tanpa bahan pengisi. Berdasarkan metode pembuatannya, dapat diklasifikasikan sebagai tablet atau tablet kompresi.

Dalam pembuatan tablet diperlukan zat tambahan yang berupa zat pengisi, zat pengikat, zat penghancur, dan zat pelicin. Dalam pembuatan tablet, zat berkhasiat, zat-zat lain kecuali pelicin dibuat granul (butiran kasar), karena serbuk yang halus tidak mengisi cetakan tablet dengan baik maka dibuat granul agar mudah mengalir mengisi cetakan serta menjaga agar tablet tidak retak. Dimana cara membuat granul 
Pemanfaatan Kulit Manggis..., Shalahuddin , Farida, Azizah

bisa dengan cara basah dan cara kering yang biasa disebut slugging atau pre compression. Pemilihan metode pembuatan tablet ini biasanya disesuaikan dengan karakteristik zat aktif yang akan dibuat tablet, apakah zat tersebut tahan terhadap panas atau lembab, kestabilannya, besar kecilnya dosis, dan lain sebagainya

Sediaan tablet banyak digunakan karena dibandingkan dengan bentuk sediaan lain, sediaan tablet mempunyai keuntunganantara lain :

1. Volume sediaan cukup kecil dan wujudnya padat (merupakan bentuk sediaan oral yang paling ringan dan paling kompak), memudahkan pengemasan, penyimpanan, dan pengangkutan.

2. Tablet merupakan bentuk sediaan yang utuh (mengandung dosis zat aktif yang tepat/teliti).

3. Dapat mengandung zat aktif dalam jumlah besar dengan volume yang kecil.

4. Tablet merupakan sediaan yang kering sehingga zat aktif lebih stabil.

5. Tablet sangat cocok untuk zat aktif yang sulit larut dalam air.

6. Zat aktif yang rasanya tidak enak akan berkurang rasanya dalam tablet.

7. Pemberian tanda pengenal produk pada tablet paling mudah dan murah.

8. Tablet paling mudah ditelan serta paling kecil kemungkinan tertinggal di tenggorokan, terutama bila bersalut yang memungkinkan pecah/ hancurnya tablet tidak segera terjadi.
9. Dapat diproduksi besar-besaran, sederhana, cepat, sehingga biaya produksinya lebih rendah.

10.Tablet merupakan bentuk sediaan oral yang memiliki sifat pencampuran kimia, mekanik, dan stabilitas mikrobiologi yang paling baik.

(The Theory \& Practice of Industrial Pharmacy, Lachman Hal 294 dan Proceeding Seminar Validasi, Hal 26)

\section{METODE PENELITIAN}

Penulisan karya tulis ilmiah ini menggunakan metode literatur. Studi literature adalah analisis kritis dari kumpulan bahan-bahan literatur yang terdiri dari sumber buku, jurnal ilmiah dan majalah ilmiah, sumber dari arsip, dokumen resmi, dan publikasi elektronik. Tujuan studi literatur dalam penulisan ini adalah sebagai dasar pembentukan rencana penulisan awal dan sebagi sumber data sekunder penulisan. Metode literatur dilakukan dengan cara pengumpulan data, pengolahan data, analisis data dan penyusunan kerangka pemikiran.

\section{Pengumpulan Data}

Pengumpulan data dilakukan dengan pengkajian bahan-bahan bacaan dalam buku, skripsi, jurnal ilmiah, jurnal elektronik, dan literatur-literatur lainnnya yang berkaitan dengan kanker, tanaman manggis, perkolasi, stabilitas obat, tablet, kelebihan tablet daripada sediaan lain, dan proses pembuatan kulit manggis menjadi tablet yang efektif untuk pengobatan kanker. Hal ini 
dimaksudkan untuk mempermudah dalam memahami permasalahan yang diungkapkan dalam karya ilmiah ini.

\section{Pengolahan Data}

Penulisan ini akan dimulai dengan pengumpulan data-data yang kemudian dikategorisasi hingga penulis dapat menguraikan bagaimana pemanfaatan kulit manggis (Garcinia mangostana L) sebagai formulasi sediaan tablet yang berpotensi sebagai anti kanker yang ramah terhadap lingkungan. Kemudian, penulis akan menguraikan tentang bagaimana pengertian kanker, klasifikasi tanaman manggis (Garcinia mangostana L), metode pembuatan tablet, kandungan tanaman manggis, dan penggunaannya sebagai agen anti kanker.

\section{Analisis Data}

Melalui bahan-bahan bacaan di atas, dilakukan pengkajian, penyeleksian, dan pencarian solusi atas masalah yang dihadapi, serta penarikan kesimpulan, sehingga kesimpulan akhir yang didapat relevan dengan masalah di lapangan dan benar-benar telah melalui penyusunan secara komprehensif berdasarkan data akurat yang dianalisis secara runtut dan tajam. Kemudian tahapan selanjutnya mengembangkan kerangka pemikiran diatas dengan pengkajian keunggulan dari formulasi sediaan tablet dibandingkan dengan sediaan lain baik dari segi stabilitas, efisiensi, dan ekonomi.

\section{PEMBAHASAN}

Pembuatan Ekstrak kulit manggis (Garcinia mangostana L) menjadi sediaan tablet yang diharapkan melalui pengujian lanjut dapat efektif digunakan untuk terapi pada penyakit kanker

\section{Alat dan Bahan}

Alat : Cawan porselen, Corong pisah, Corong saring, Penangas air

Bahan : $\mathrm{BuOH}, \mathrm{CH}_{2} \mathrm{Cl}_{2}$, EtOAc, Kertas saring, Kulit manggis, Methanol, $\mathrm{n}$-hexana

\section{Determinasi Tanaman}

Determinasi tanaman manggis (Garcinia mangostana L) berpedoman pada buku acuan "Flora of Java" (Backer dan Brink, 1965).

\section{Penyiapan Simplisia}

Kulit manggis (Garcinia mangostana L) yang digunakan adalah tanaman yang diambil dari perkebunan manggis (Garcinia mangostana L) dan diambil hanya kulit bagian dalamnya yang berwarna merah hati.

Pembuatan Granul Ekstrak Kulit Manggis (Garcinia mangostana L)

1.Dipilih kulit manggis (Garcinia mangostana $\mathrm{L}$ ) yang sudah masak, berwarna merah hati

2. Kulit manggis dikeringkan dan digiling dengan blender

3. Serbuk yang didapat diekstraksi dengan metode perkolasi 
Pemanfaatan Kulit Manggis..., Shalahuddin , Farida, Azizah

4. Didapat ekstrak cair pekat, kemudian diekstraksi dengan kromoform

5. Ekstrak yang didapat ditambahkan dengan malto dekstrin

6. Ekstrak kering kemudian ditambahkan dan dicampur dengan eksipient

7. Dilakukan proses granulasi menggunakan metode granulasi kering

8. Dilakukan uji terhadap granul

9. Dilakukan proses penabletan

10. Dilakukan uji terhadap tablet

11. Tablet yang sudah jadi dan telah diuji kemudian dikemas

\section{Ekstraksi dan Isolasi}

1. Kulit manggis dikeringkan dan digiling sebanyak 1 kg kemudian dimaserasi menggunakan methanol selama 3 hari, disaring dan dipekatkan

2. Ekstrak methanol (207 g) dilarutkan dalam air kemudian dipartisi dengan n-hexana (3x500 ml), $\mathrm{CH}_{2} \mathrm{Cl}_{2}(3 \times 500$ $\mathrm{ml})$, EtOAc $(3 \times 500 \mathrm{ml})$ dan $\mathrm{BuOH}$ $(3 \times 500 \mathrm{ml})$

3. Ekstrak etil asetat digunakan untuk fraksinasi menggunakan VLC dalam berbagai komposisi sistem pelarut

4. Fraksi yang digunakan untuk proses pemurnian adalah fraksi 3 menggunakan preparatif kromatografi kolom dengan pelarut hexane : etil asetat (2:8) untuk menghasilkan 3 senyawa, senyawa 1 (12 mg), senyawa 2 (3 mg), dan senyawa 3 (6 mg)

\section{Desain Formula Tablet}

Formula tablet dari kulit manggis (Garcinia mangostana L) ini dengan variasi pada bahan pelincir dan pengikat dari tablet.

Tabel 1. Formula tablet ekstrak kulit manggis (Garcinia mangostana L)

\begin{tabular}{|l|l|l|l|}
\hline Bahan & Formula 1 (mg) & Formula 2 (mg) & Formula 3 (mg) \\
\hline Ekstrak & 250 & 250 & 250 \\
\hline Laktosa & 675 & 675 & 675 \\
\hline Asam sitrat & 320 & 320 & 320 \\
\hline Asam tartat & 640 & 640 & 640 \\
\hline Na bikarbonat & 1100 & 1100 & 1100 \\
\hline Peg 6000 & 10 & 10 & 10 \\
\hline Aspartam & 90 & 90 & 90 \\
\hline PVP & 1,75 & 2,5 & 3,25 \\
\hline
\end{tabular}

(Febrianti, 2008)

\section{Senyawa Xanton}

Senyawa xanthone merupakan golongan senyawa fenolik. Senyawa ini dapat diisolasi dari family Garcinia, salah satu spesienya Garcinia mangostana $\mathrm{L}$. Jenis senyawa xanthone yang terdapat dalam manggis yaitu amangostin. Ekstrak a-mangostin ini didapat dari kulit buah manggis yang berwarna merah hati. Dalam sebuah jurnal yang dibuat oleh Oktaviani, memaparkan hasil penelitiannya bahwa senyawa a-mangostin berpotensi sebagai anti kanker. Dalam penelitiannya, ia menggunakan tikus yang diinduksi benzapiren, zat pemicu kanker sebagai control positif dan sebagai control negatifnya yaitu tikus normal (tikus tanpa benzapiren). Hasilnya yaitu senyawa a-mangostin yang diberikan 
bekerja dengan prinsip antioksidan dimana a-mangostin mendonasikan proton yang akan menangkap benzapiren sehingga menyebabkan benzapiren menjadi senyawa non- radikal.

Dalam jurnal lain, Jurnal Pharmacy and Pharmacology, Younghwa Na juga menuliskan bahwa senyawa xanthon, khususnya a-mangostin memiliki akitivitas sebagai anti kanker. Younghwa menjelaskan bahwa a-mangostin bekerja dengan cara menghambat pertumbuhan sel dari garis sel manusia leukemia dengan menginduksi caspase-3 apoptosis. Sehingga dari hasil ini menyatakan bahwa senyawa xanthone khususnya a-mangostin positif berpotensi sebagai anti kanker.

\section{Dosis Xanthone}

Penggunaan kulit manggis (Garcinia mangostana $\mathrm{L}$ ) yang ada di pasaran yaitu dalam bentuk sediaan sirup, dengan nama Xanthone Plus dengan dosis sekali minum $30 \mathrm{ml} /$ minum, sehari maksimal tiga kali minum.

\section{Stabilitas sediaan tablet yang diformulasi dari kulit manggis (Garcinia mangostana L)}

Tablet adalah sediaan bentuk padat yang mengandung substansi obat dengan atau tanpa bahan pengisi. Sediaan tablet banyak digunakan di masyarakat karena memiliki beberapa keuntungan salah satunya ialah dapat menutupi rasa dan bau yang tidak enak dari obat. Kulit manggis memiliki rasa yang sepat sehingga dalam sediaan sirup rasa ini sulit untuk tertutupi. Akan tetapi dalam formulasi sediaan tablet, rasa sepat yang dimiliki oleh kulit manggis ini dapat tertutupi.

Senyawa xanthon sendiri tidak dipengaruhi oleh $\mathrm{pH}$ dan tahan panas sampai dengan $95 \mathrm{C}$ aktivitasnya masih cukup bagus. Tablet merupakan sediaan dalam bentuk kering sehingga zat aktif yang terkandung di dalamnya lebih stabil. Stabilitas sangat diperlukan dalam sediaan farmasi karena stabilitas merupakan kemampuan suatu obat untuk mempertahankan sifat dan karakteristiknya agar sama dengan yang dimilikinya pada saat dibuat dalam batasan yang ditetapkan sepanjang periode penyimpanan dan penggunaan (Ahmat, 2010).

Sediaan tablet kulit manggis (Garcinia mangostana L) berpotensi dapat diterima masyarakat dengan pertimbangan praktis dan nilai ekonomis dengan perbandingan harga produk sejenis yang ada di pasaran.

\section{Kepraktisan Sediaan Tablet}

Sediaan xanthone yang ada di pasaran saat ini adalah dalam bentuk sirup dengan kemasan botol, hal ini merugikan konsumen karena harus membawa botol ketika akan menggunakannya. Belum lagi komposisi dengan tambahan gula yang ada pada sirup di dalamnya yang tentunya berbahaya untuk pasien penderita gula darah. 
Tablet kulit manggis (Garcinia mangostana L) merupakan bentuk alternatif terbaik dalam pemanfaatan kulit manggis sebagai anti kanker. Selain praktis dibawa kemana-mana, tablet juga tidak mudah terhidrolisis sehingga stabilitasnya lebih terjaga.

Tablet merupakan bentuk sediaan yang paling banyak beredar di masyarakat karena secara fisik stabil, mudah dibuat, lebih menjamin kestabilan bahan aktif disbanding dengan bentuk cair. Selain itu juga tablet juga mudah dibuat, dikemas, mudah digunakan, homogen dan reproducible.

Keunggulan lain sediaan tablet yaitu mudah dibawa kemana-mana. Tablet hanya membutuhkan tempat yang relatif kecil disbanding dengan sirup dalam botol. Kemasan botol terutama botol kaca juga rawan pecah dan ketika meminumnya juga membutuhkan keadaan yang setenang mungkin. Dalam sekali pakai dengan dosis $30 \mathrm{ml}$ juga tidak dapat langsung sekali minum jika menggunakan sendok makan karena sendok makan memiliki volume sekitar $5 \mathrm{ml}$. Sedangkan apabila dalam bentuk tablet dapat dipakai dengan sekali minum dengan menggunakan air dan dapat langsung diminum meskipun sedang dalam perjalanan atau berada dalam kendaraan.

\section{Perbandingan Ekonomis}

Perbandingan ekonomis ini dimaksudkan untuk mengetahui kisaran biaya yang diperlukan untuk pembuatan tab- let yang kemudian dibandingkan dengan sediaan sirup yang ada di pasaran. Pembuatan tablet yang relatif murah menjadikan banyak sediaan farmasi yang berbentuk tablet. Biaya yang dikelurkan untuk pembuatan tablet $x a n$ thone kurang Rp.3.000,00 per tablet. Apabila dibandingkan dengan harga sirup xanthone, harga tablet jauh lebih murah. Dalam sebuah sirup penjualan sirup xanthone, harga sirup dengan ukuran $250 \mathrm{ml}$ yaitu $\mathrm{Rp} 75.000,00$. Dosis setiap kali minum yaitu $30 \mathrm{ml}$, sehingga bila dihitung dalam sekali minum mengeluarkan biaya sekitar $\mathrm{Rp}$ $9.300,00$.

Tabel 2. Rancangan biaya pembuatan per tablet

\begin{tabular}{|l|l|l|}
\hline Bahan & Harga Satuan & Formula 1 \\
\hline Ekstrak & Rp. 65.000/ kg & Rp. 16, 25 \\
\hline Laktosa & Rp. 2.000/gram & Rp. 1.300 \\
\hline Asam sitrat & Rp. 125/ gram & Rp. 40 \\
\hline Asam tartat & Rp. 2.200/gram & Rp.1.408 \\
\hline Na bikarbonat & Rp. 153/gram & Rp.168,3 \\
\hline Peg 6000 & Rp. 125/ gram & Rp.1,25 \\
\hline Aspartam & Rp. 220/ gram & Rp.19,8 \\
\hline PVP & Rp. 5000/gram & Rp. 8,75 \\
\hline Jumlah & & Rp. 2.962, 35 \\
\hline
\end{tabular}

\section{Uji Responden}

Uji responden ini dimaksudkan untuk mengetahui dapat tidaknya sediaan tablet dari ekstrak kulit manggis (Garcinia mangostana L) diterima oleh masyarakat dengan pertimbangan nilai ekonomis, kemasan.

Dari 30 orang sebagai responden didapatkan data untuk segi kemasan 18 
orang lebih memilih sediaan tablet, sedangkan dari segi ekonomis/ harga 26 orang lebih memilih tablet daripada sirup karena dengan potensi yang sama harga tablet dinilai lebih murah daripada sirup. Dari hasil responden ini menjelaskan bahwa bentuk sediaan tablet berpotensi diterima masyarakat dengan pertimbangan segi praktis dan ekonomis.

Tabel 3. Uji responden terhadap segi kemasan dan ekonomis tablet.

\begin{tabular}{|l|l|l|}
\hline \multirow{2}{*}{\multicolumn{1}{c|}{ Respon }} & \multicolumn{2}{c|}{ Pilihan } \\
\cline { 2 - 3 } & Tablet & Sirup \\
\hline Segi Kemasan & 18 & 12 \\
\hline Segi ekonomis/ harga & 26 & 4 \\
\hline Jumlah & 30 & 30 \\
\hline
\end{tabular}

\section{PENUTUP}

\section{Kesimpulan}

Kesimpulan yang bisa diambil dari hasil penulisan ini adalah:

1.Tablet kulit manggis (Garcinia mangostana $\mathrm{L}$ ) diharapakan efektif digunakan untuk terapi pengobatan kanker

2. Tablet kulit manggis yang stabil melalui uji kelayakan terstandar

3. Tablet kulit manggis (Garcinia mangostana $\mathrm{L}$ ) dapat diterima oleh masyarakat dengan pertimbangan bentuk sediaan, nilai ekonomis, kepraktisan sediaan tablet, dan efektifitas.

\section{Rekomendasi}

1. Penelitian selanjutnya diharapkan untuk melakukan uji keefektifan dan uji zat aktif yang mungkin masih tertinggal dalam sediaan tablet kulit manggis (Garcinia mangostana L).

2. Diharapkan penelitian lebih lanjut unntuk mengetahui dosis maksimum tablet yang dihasilkan dari kulit manggis (Garcinia mangostana L) dapat efektif sebagai anti kanker.

3. Perlu dilakukan uji zat lain yang terdapat pada kulit manggis yang kemungkinan dapat menjadi efek samping.

\section{DAFTAR PUSTAKA}

Ahmat, Norizan., et. al., 2010, Bioactive xanthones from the Pericarp of Garcinia mangoatana, Universiti Teknologi MARA. Selangor, Malaysia 123-127

Anief, Moh. Farmasetika. Yogyakarta: UGM Press

Anonim. 2009. Rencana Pembangunan Jangka Panjang Bidang Kesehatan 2005-2025. Jakarta: Departemen Kesehatan RI

Anonim.2012a .http://health.detik.com/ read/2012/08/30/165020/2003530/ 763/jumlah-penderita-kanker-didunia-naik-300-persen-pada-tahun2030, diakses november 2012

Anonim. 2012 ${ }^{\mathrm{b}}$. http://id.wikipedia.org/ wiki/Kanker, diakses november 2012 Anonim. 2012 ${ }^{c}$. Manggis, dikutip dari http://www.wikipedia.org/wiki/ Manggis, pada tanggal 4 November 2012.

Backer. C.A., Van De Brink, R.C.B., 1965. Flora of Java, II, N.N.P. 
Pemanfaatan Kulit Manggis..., Shalahuddin , Farida, Azizah

Noordhoff Groningen. The Netherlands

Asep, 2012."Khasiat Buah Manggis dan Manfaat Kulit Manggis Bagi Kesehatan". dikutip dari http:// obatalamihipertensi.net/1882/ manfaat-kulit-manggis/, pada tanggal 4 November 2012.

Febrianti, Yosi, dkk. 2008. Teknologi Formulasi Tablet Efferfescent dari Ekstrak Daun Jambu Biji Merah dan Putih (Psidium Guajava L) dengan Metode Spray Dryer: Peningkatan Sediaan Herbal untuk Terapi Pengobatan Penyakit Demam Berdarah (DBD). Yogyakarta: Khazanah

Hoffmann, David, 2003, Medical Herbalism : The Science and Practice of Herbal Medicine, Ronchester - Vermont : Healing Arts Press.

Isa. 2009. Gaya Hidup Sehat Alami. Jakarta: Tiens

Jamil, Dwi Oktaviani, Ersam, Taslim. 2010.Pelacakan Aktivitas Antikanker Terhadap Tiga Senyawa Santon Terprenilasi Dari Spesies Garcinia. Surabaya : Fakultas MIPA, Instutur Teknologi Sepuluh November.

Lachman. The Theory \& Practice of Industrial Pharmacy, Hal 294 dan Proceeding Seminar Validasi, Hal 26

Mitchell, Richard N.,et al, 2006, Pocket Companion to Robbins \& Contran Pathologic basic of Disease, $7^{\text {th }}$ Edition, diterjemahkan Oleh Andri
Hartono, Penerbit Buku Kedokteran EGC, Jakarta

$\mathrm{Na}$, Younghwa. 2009.Recent Cancer Drug Development with Xanthone Structures, College of Pharnacy, Catholic University of Daegu, Gyeongsan, Gyeongbuk. Korea.

Nugrahani, IIman, dkk. 2005. Karakteristik Granuldan Tablet Propanolol Hidroklorida dengan Metode Granulasi Peleburan. Majalah ilmu kefarmasian, Vol.II, No.2 Hal.101 .Departemen Farmasi FMIPAUI.

Price, Sylvia A., Wilson, Lorraine M., 1992, Pathopsiology, Clinical Conceps of Disease Processes, Fourt Edition, diterjemahkan oleh Peter Anugerah tahun 1995, Penerbit Buku Kedokteran EGC, Jakarta

Voight. 1984. Buku Pelajaran Teknologi Industri, diterjemahkan oleh Noerono., S. Edisi V. Yogyakarta: Gadjah Mada University Press 